Аль-Атті Ірина Василівна доктор філософії і галузі 281 «Публічне управління та адміністрування, адвокат, адвокатське об'єднання «Мірлєкс», вул. Глибочицька, 17А, м. Київ, 04050, тел.: (067) 141-41-42, e-mail: pkoi@ukr.net, https://orcid.org/0000-0002-6682-4200

Коцур Віталій Вікторович доктор історичних наук, доцент, декан факультет гуманітарно-природничої освіти і соціальних технологій ДВНЗ «Переяслав-Хмельницький державний педагогічний університет імені Григорія Сковороди», вул. Сухомлинського, 30, м. Переяслав, 08400, тел. (066) 656-69-22, e-mail: kotsurv@ukr.net, https://orcid.org/0000-0001-6647-7678

\title{
ТЕОРЕТИЧНІ ПІДХОДИ ДО ПРОБЛЕМИ РОЗВИТКУ СУЧАСНОЇ МОДЕЛІ ПУБЛІЧНОГО УПРАВЛІННЯ
}

Анотація. Систематизовані проблеми розвитку національної моделі публічного управління. Зауважено, що проблема розвитку публічного управління невід'ємна від розвитку інституту місцевого самоврядування, i вирішення ії виходить за межі суто адміністративної реформи, спрямованої на оптимізацію системи та механізму реалізації виконавчої влади. Але тим актуальнішим є завдання цілеспрямованого формування та модернізації інститутів державної влади, утвердження демократичних засад їх діяльності, здатних найбільшою мірою забезпечити ефективний розвиток суспільства $\mathrm{i}$ держави. Проведений аналіз дав можливість виокремити шість кластерів проблем публічного управління, зокрема: по-перше, відсутність нормативноправового регулювання поняття «публічне управління», як єдиної системи функціонування державного управління та місцевого самоврядування, а також органів влади, державних та комунальних підприємств, установ, організацій; по-друге, відсутність системності реформування та розвитку публічного управління; по-третє, відсутність дієвого корпусу публічної служби, яка не врегульована як інституція. Саме публічна служба є основою ефективних реформ системи публічного управління; по-четверте, відсутність системного, комплексного механізму запровадження децентралізації в Україні; по-п'яте, фрагментарність реформування публічного управління, яка пов'язана 3 постійними змінами політичного курсу країни; по-шосте, відсутність правонаступництва та послідовності реалізації реформування в системі публічного управління. Це негативно впливає на це реформи, які це не були повністю реалізовані, оскільки це є проблеми у забезпечені розвитку певної галузі в даному означеному напрямку.

Ключові слова: публічне управління, система органів державної влади, публічна служба, органи місцевого самоврядування, Європейський Союз, міжнародно-правові стандарти. 
Al-Atti Irina Vasylivna Ph.D. 281 Public Administration, Lawyer, Attorney association "Mirlex", Hlybochytska St., 17A, Kyiv, 04050, tel.: (067) 141-41-42, e-mail: pkoi@ukr.net, https://orcid.org/0000-0002-6682-4200

Kotsur Vitalii Viktorovych Doctor of Historical Sciences, PhD in Political Sciences, Assistant Professor, Dean of Faculty of Humanitarian and Natural Education and Social Technologies of Pereiaslav-Khmelnytskyi Hryhorii Skovoroda State Pedagogical University, Sukhomlinskoho St., 30, Pereyaslav, 08400, тел. (066) 656-69-22, e-mail: kotsurv@ukr.net, https://orcid.org/00000001-6647-7678

\title{
THE ORETICAL APPROACHES TO THE PROBLEM OF DEVELOPMENT OF THE MODERN MODEL OF PUBLIC GOVERNANCE
}

\begin{abstract}
The article systematizes the problems of development of the national model of public administration. The authors note that the problem of public administration development is inseparable from the development of the institution of local self-government, and its solution goes beyond a purely administrative reform aimed at optimizing the system and mechanism of executive power. But the more urgent is the task of purposeful formation and modernization of institutions of state power, the establishment of democratic principles of their activities that can best ensure the effective development of society and the state. The analysis made it possible to identify six clusters of public administration problems, in particular: first, the lack of legal regulation of the concept of "public administration" as a single system of public administration and local government, as well as government, state and municipal enterprises organizations; secondly, the lack of systematic reform and development of public administration; third, the lack of an effective public service body that is not regulated as an institution. It is the public service that is the basis for effective reforms of the public administration system; fourth, the lack of a systematic, comprehensive mechanism for the introduction of decentralization in Ukraine; fifth, the fragmentary nature of public administration reform, which is associated with constant changes in the country's political course; sixth, the lack of succession and consistency in the implementation of reforms in the public administration system. This negatively affects the reforms, which have not been fully implemented, as these are problems in ensuring the development of a particular industry in this area.
\end{abstract}

Keywords: public administration, system of public authorities, public service, local self-government bodies, European Union, international legal standards.

Постановка проблеми. Сьогодні багато уваги науковців акцентується на необхідності зміни моделі вітчизняного публічного управління. Україна обрала європейський вектор розвитку у всіх сферах життя. Однак, європейська цивілізаційна модель управління - це досить складний соціальний, демократичний та правовий перехід до політично 
організованого, відповідального громадянського суспільства нової якості, в якому $\epsilon$ досить високий рівень ділової активності та політичної участі громадян, забезпечення їхніх прав і свобод.

Наразі в Україні основна можливість взаємного обміну досвідом у сфері публічного управління здійснюється за допомогою міжнародної співпраці. Тому саме на підставі аналізу як зарубіжних, так й вітчизняних наукових досліджень, можна розробити, спроектувати, визначити головні етапи розвитку публічного управління в Україні із врахуванням головних та важливих міжнародно-правових норм, традицій та принципів.

Наявна в Україні модель управління справляється із сучасними викликами і тенденціями суспільного розвитку не найкращим чином, та актуалізує невідкладність пошуку і забезпечення становлення нової моделі, яка б прискорила позитивні очікувані зміни в суспільстві.

Аналіз останніх досліджень і публікацій. Проблеми системи публічного управління в Україні, сучасних аспектів розвитку публічного управління, інноваційних моделей публічного управління аналізують багато вчених, у тому числі: О.Антонова, В.Баштанник, О.Борисенко, В.Брагінського, К.Герасимюк, Н.Гнидюк, М.Калина, А.Карапетян, Д.Красівський, О.Коліжук, С.Мамедов, М.Назаренко, О.Оболенський, Т.Паламарчук, О.Пархоменко-Куцевіл, В.Попович, В.Роман, Р.Сорока, В.Тихонович, О.Червякова, М.Чулаєвська, Д.Юрковський.

Однак, незважаючи на достатню кількість публікацій у науковому просторі України, присвячених реформуванню публічного управління, переважна більшість із них має галузеву спрямованість або прикладний характер, в них не розглядається удосконалення державного управління в умовах трансформаційних перетворень в українському суспільстві.

Метою статті $\epsilon$ систематизація теоретичних підходів до проблеми розвитку сучасної моделі публічного управління в Україні.

Виклад основного матеріалу. Проблеми реформування системи публічного управління виявили ряд проблем сучасних моделей реформування публічного управління, а також проблеми розвитку національної моделі публічного управління.

Вивчення проблем розвитку публічного управління дуже популярне у розвинутих країнах світу. Сьогодні ж в Україні ще не маємо навіть чіткого означення цього поняття, яке було б загальнозрозумілим. Поява нової форми управління у публічній сфері була спричинена потребою модернізувати організаційні структури і процедури, які вони використовують, для того щоб усі інституції публічної сфери працювали краще. Публічне управління стосується ефективного функціонування всієї системи політичних інституцій і сьогодні [1, с. 46].

Аналіз сучасних державно-правових тенденцій розвитку системи публічного управління свідчить про домінування трьох основних i взаємопов'язаних напрямів. Перший - адміністративно-правове вдосконалення державного апарату на засадах системного та комплексного підходів, адже цілісність держави може забезпечуватися лише через 
цілісність організації та функціонування їі апарату. Другий напрям полягає у зміцненні механізмів публічного управління через удосконалення i практичне забезпечення постійних взаємозв'язків між інститутами громадянського суспільства та органами державної влади. Третій напрям подальше оновлення адміністративних правил i процедур державнослужбової діяльності з метою підтримання внутрішньої безпеки держави [2].

Водночас, рівень системності організації державного управління в Україні залишається поки що невисоким, а такі риси, як цілісність і функціональна спеціалізація, виражені в ній недостатньо чітко

На думку О. Мельниченко, нині “одним із стратегічних завдань під час адміністративного реформування $є$ формування нової ідеології функціонування виконавчої влади та місцевого самоврядування як діяльності, в основу якої покладається забезпечення реалізації прав і свобод громадян, надання якісних і вчасних публічних послуг. Відповідно, система державного управління має змінити свою парадигму в бік публічного управління". При цьому основною метою такої зміни є “наближення влади до народу, що має відбуватися шляхом пробудження в останнього інтересу до державотворчого процесу, перетворення громадськості на активного суб'єкта політичних відносин, наділеного як реальними інструментами ініціювання владних проектів, так i можливістю контролю за їх реалізацією" [3].

Багато науковців зауважують, що сучасна західна модель адміністрування пов'язана 3 економічним підходом до публічного управління. 3 урахуванням ускладнення взаємозалежностей між державними, приватними та некомерційними організаціями при формуванні та реалізації державної політики неминуче зростає роль ринкових відносин в державному секторі. В результаті концепція адміністративної держави заміщується концепцією ефективної, маловитратної держави. Таке трактування публічного управління укладається в парадигму теорії державного менеджменту. Його особливості знайшли своє вираження в принципах, сформульованих Д. Осборном і Т. Геблером в їх знаменитій праці «Перебудова уряду» [4]. До них віднесені субсидіарність сучасної організації управління, яке повинно бути ближче до клієнта; децентралізація управління, чіткий розподіл повноважень і функцій; вміння працювати в команді; поєднання громадських інтересів 3 інтересами конкретної людини; діяльність, орієнтована на результат, якість послуг і рентабельність. У зв'язку 3 цим Л. Сморгунов і С.Морозова справедливо зауважують, що новий державних менеджмент базується на передумовах теорії раціонального вибору та ринкових установках щодо публічних справ, підкреслюють конкурентність, можливість вибору, обмін ресурсами і оптимальність [4].

Впровадження менеджеристських засад в управління дозволяє, як показує практика, здійснювати:

1) правовий контроль за діяльністю будь-якого чиновника (на відповідність його дій закону),

2) фінансовий контроль (в частині використання бюджетних коштів), 
3) демократичний контроль (на предмет взаємодії 3 громадянами та громадськими об'єднаннями),

4) етичний контроль (на відповідність дій і вчинків етичним нормам).

Разом 3 тим це потребує виокремлення інноваційних механізмів розвитку та реформування сучасного публічного управління.

Однією з головних складових реформування виконавчої влади й системи органів, які iï здійснюють, є чітке визначення i нормативне закріплення функцій центральних органів виконавчої влади як і функцій всієї системи, різних ланок органів виконавчої влади. Проблема функціональної спеціалізації та додержання організаційної типологізації найбільш гостро стоїть для системи центральних органів виконавчої влади. Непоодинокими є випадки організаційного суміщення функцій, які мають реалізовуватися різними видами центральних органів виконавчої влади, в одному органі. Це не тільки не відповідає вимогам Закону України "Про центральні органи виконавчої влади", але й не дозволяє чітко розмежувати функції та управлінські сфери відповідальності таких органів, несе потенційну загрозу конфлікту інтересів. Усуненню цього недоліку сприятиме уточнення функцій та компетенції відповідних органів управління на засадах організаційноправового розмежування функцій міністерств як органів, що забезпечують формування та реалізують державну політику у визначеній сфері, здійснюючи при цьому забезпечення нормативно-правового регулювання, визначення пріоритетних напрямів розвитку, інформування та надання роз'яснень щодо здійснення державної політики, 3 функціями інших центральних органів виконавчої влади - наданням адміністративних послуг, здійсненням державного нагляду (контролю) та управлінням об'єктами державної власності [5, с. 6-7].

Фактична конструкція системи державного управління в Україні на сьогоднішній день має істотні відмінності від своєї нормативної моделі. Це пов'язано не лише 3 недостатнім додержанням вимог функціональної спеціалізації та організаційної типологізації органів виконавчої влади, але й невідповідністю створюваних центральних органів виконавчої влади тим, які передбачені у законах, або взагалі їх відсутністю. Наприклад, законами України у сфері управління транспортом передбачено створення та функціонування національної комісії, що здійснює державне регулювання у сфері транспорту, яка й досі не сформована. Крім того, спостерігається невідповідність визначеного законами України та підзаконними нормативними актами, в тому числі й положеннями про центральні органи виконавчої влади, функціонального спрямування діяльності окремих таких органів [5, с. 6-7].

Проблема розвитку місцевої та регіональної ланки системи державного управління невід’ємна від розвитку інституту місцевого самоврядування, i вирішення їі виходить за межі суто адміністративної реформи, спрямованої на оптимізацію системи та механізму реалізації виконавчої влади. Але тим актуальнішим є завдання цілеспрямованого формування та модернізації інститутів державної влади, утвердження демократичних засад їх діяльності, 
здатних найбільшою мірою забезпечити ефективний розвиток суспільства $\mathrm{i}$ держави [6, с. 284].

Останнім часом було здійснено низку заходів організаційного та нормативно-правового характеру 3 метою реформування системи адміністративних послуг. Вони сприяли спрощенню доступу громадян до адміністративних послуг, підвищенню зручності їх отримання, поліпшенню якості адміністративних послуг. Разом із цим подальшому реформуванню системи адміністративних послуг має сприяти прийняття Закону України “Про перелік адміністративних послуг та плату (адміністративний збір) за їх надання", Адміністративно-процедурного кодексу України, а також вирішення питань оптимального розподілу повноважень між органами державної влади та органами місцевого самоврядування щодо надання таких послуг [7, с. 51].

Поряд 3 цим вимагають подальшого цілеспрямованого розвитку механізми електронного урядування. Попри те, що запровадження їх визнано одним із стратегічних напрямів модернізації державного управління, постійно приймаються 3 цих питань акти нормативного та організаційнорозпорядчого характеру, останнім часом спостерігалися тенденції уповільнення впровадження електронного урядування. Це ставить завдання щодо критичного перегляду державної політики, iii раціоналізації та підвищення результативності у цій сфері.

Проведений аналіз дає підстави виокремити наступні проблеми публічного управління, зокрема:

по-перше, відсутність нормативно-правового регулювання поняття «публічне управління», як єдиної системи функціонування державного управління та місцевого самоврядування, а також органів влади, державних та комунальних підприємств, установ, організацій;

по-друге, відсутність системності реформування та розвитку публічного управління;

по-третє, відсутність дієвого корпусу публічної служби, яка не врегульована як інституція. Саме публічна служба $\epsilon$ основою ефективних реформ системи публічного управління;

по-четверте, відсутність системного, комплексного механізму запровадження децентралізації в Україні;

по-п'яте, фрагментарність реформування публічного управління, яка пов'язана з постійними змінами політичного курсу країни;

по-шосте, відсутність правонаступництва та послідовності реалізації реформування в системі публічного управління. Це негативно впливає на це реформи, які це не були повністю реалізовані, оскільки це є проблеми у забезпечені розвитку певної галузі в даному означеному напрямку.

Висновки. У статті проаналізовані наукові підходи до проблем розвитку сучасної моделі публічного управління в Україні. Виокремлено шість кластерів проблем, у тому числі: відсутність системності реформування та розвитку публічного управління; відсутність дієвого корпусу публічної служби, яка не врегульована к інституція; відсутність системного, 
комплексного механізму запровадження децентралізації в Україні; фрагментарність реформування публічного управління, яка пов'язана 3 постійними змінами політичного курсу країни; відсутність правонаступництва та послідовності реалізації реформування в системі публічного управління.

\section{Jimepamypa:}

1. Татаренко В. Б. Система публічного адміністрування в Україні: становлення та розвиток. Державне управління: наукові праці. 2012. Вип. 169. Том 181. С. 45-48.

2. Битяк Ю.П. Напрями розвитку системи державного управління та їі правове забезпечення. Теорія та практика державного управління. 2014. Вип. 4 (47). URL: http://www.kbuapa.kharkov.ua/e-book/tpdu/2014-4/doc/1/01.pdf

3. Мельниченко О. А. Якість публічного управління як запорука добробуту населення країни. Актуальні проблеми державного управління. 2017. 1(51). C.1-7. URL: http://www.kbuapa.kharkov.ua/e-book/apdu/2017-1/doc/1/01.pdf.

4. Osborne D., Gaebler T. Reinventing Government: How the enterprencurial spirit is transforming the public sector. N. Y., 1992.

5. Георгієвський Ю. До питання визначення критеріїв розмежування компетенції органів державної виконавчої влади та органів місцевого самоврядування. Віче. 2014. № 14. C. $6-9$

6. Домбровський О. Децентралізація влади: історія, проблеми, перспективи. Проблеми децентралізаџії: національний та міжнародний досвід / наук. ред. М. Пухтинський. К. : Атіка - Н., 2006. С. 283-291.

7. Костюк I. Зарубіжний досвід реалізації адміністративних реформ: порівняльний аналіз правового забезпечення. Державне управління та місиеве самоврядування : зб. наук. пр. 2013. Вип. 4 (19). С. 50-58.

\section{References:}

1. Tatarenko V. B. (2012) Systema publichnoho administruvannia v Ukraini: stanovlennia ta rozvytok [The system of public administration in Ukraine: formation and development]. Derzhavne upravlinnia: naukovi pratsi - Public administration: scientific works. (169) (181); 45-48 [in Ukrainian].

2. Bytiak Yu.P. (2014) Napriamy rozvytku systemy derzhavnoho upravlinnia ta yii pravove zabezpechennia [Directions of development of the public administration system and its legal support]. Teoriia ta praktyka derzhavnoho upravlinnia - Theory and practice of public administration. (4) (47). Retrieved from: http://www.kbuapa.kharkov.ua/e-book/tpdu/20144/doc/1/01.pdf [in Ukrainian].

3. Melnychenko O. A. (2017)Yakist publichnoho upravlinnia yak zaporuka dobrobutu naselennia krainy [Quality of public administration as a guarantee of welfare of the population]. Aktualni problemy derzhavnoho upravlinnia -Actual problems of public administration. (1) (51); 1-7. Retrieved from: http://www.kbuapa.kharkov.ua/e-book/apdu/2017-1/doc/1/01.pdf. [in Ukrainian].

4. Osborne D., \& Gaebler T. (1992) Reinventing Government: How the enterprencurial spirit is transforming the public sector. N. Y. [in English].

5. Heorhiievskyi Yu. (2014) Do pytannia vyznachennia kryteriiv rozmezhuvannia kompetentsii orhaniv derzhavnoi vykonavchoi vlady ta orhaniv mistsevoho samovriaduvannia [On the question of determining the criteria for delimiting the competence of state executive bodies and local governments]. Viche - Viche. (14); 6-9. [in Ukrainian]. 
6. Dombrovskyi O. (2006) Detsentralizatsiia vlady: istoriia, problemy, perspektyvy [Decentralization of power: history, problems, prospects.]. Problemy detsentralizatsii: natsionalnyi ta mizhnarodnyi dosvid - Problems of decentralization: national and international experience / nauk. red. M. Pukhtynskyi. K. : Atika - N., (283-291) [in Ukrainian].

7. Kostiuk I. (2013) Zarubizhnyi dosvid realizatsii administratyvnykh reform: porivnialnyi analiz pravovoho zabezpechennia [Foreign experience in implementing administrative reforms: a comparative analysis of legal support]. Derzhavne upravlinnia ta mistseve samovriaduvannia : zb. nauk. pr. - Public administration and local self-government: coll. Science. etc., Vyp. 4 (19); 50-58 [in Ukrainian]. 